\title{
Political Attitudes of China's and the U.S.'s Future Elites toward Governance and Their Implications for Southeast Asia
}

\author{
Sugumaran Narayanan and Wanfa Zhang
}

\begin{abstract}
Will Southeast Asia become a politically safer place in the future? Can we hope for the U.S., the world's largest power, and China, the world's most prominent rising power to achieve these goals? If a regional power is clean and is able to control corruption, we may assume that it is responsible, and therefore expect the region to be safer. With the $21^{\text {st }}$ century commonly referred to as the "Asian century" how will South East Asia prepare itself to face the challenges of a volatile region? One measure of stability is the movement of regional powers from more autocratic to more democratic. This study selected Asia's most prominent state, China, the most obvious rising power, as a case study. A method used to dissect China's good governance topic is by the use of survey questionnaires. A second case analyzed was the United States. American students were surveyed on their perceptions of good governance. The study analyzed the current trend with regards to efficiency, effectiveness, corruption, and clean government. From the analysis, the study aims to predict the direction in which current and future leaders of the world in general, and the U.S. and China in particular, will steer the world and Southeast Asia? Results indicating a conservative Chinese view versus a more liberal U.S. view could pose problems for future China-ASEAN relations.
\end{abstract}

Index Terms-Southeast Asia, China, United States, governance, survey.

\section{INTRODUCTION}

This research intends to find China's and United States' good governance performance as perceived by current college students in an attempt to predict future leaders (current students) acceptance of their governments in the years to come. This paper seeks to directly solicit opinions and attitudes at nearly 30 universities in different parts of China, from elite universities such as Peking University and China Foreign Affairs University to minor and less salient universities in the Southwest of China. Additionally there are almost 15 universities surveyed in the U.S. and the number is gradually increasing. Student majors cover almost all disciplines and majors. The idea is to discover what and how the students think about a series of political and governance issues and if/how the Chinese regime or the U.S. has been satisfying their views and wants. If what the current regime provides to the Chinese and American societies conforms to the students' wants and needs, it would mean that the current governance is acceptable to the future generation. If the

Manuscript received November 15, 2016; revised March 1, 2017.

Sugumaran Narayanan is with Midwestern State University, Wichita Falls, TX 76308 USA (e-mail: narasugu@yahoo.com).

Wanfa Zhang is with Florida Institute of Technology, Melbourne, FL 32901 USA (e-mail: wzhang@ fit.edu). survey finds that China is practicing, or beginning to practice good governance, then we may assume that Southeast Asia is becoming a safer region.

\section{LITERATURE REVIEW}

\section{A. Literature Review on Good Governance}

\section{Definitions, Concepts, and Brief Literature}

At a glance, the phrase good governance does not seem to portray much. Additionally, the phrase paints a rather simple picture. Good governance however is not a concept that is as straightforward as it seems to be. Agencies and scholars have disagreed with, and not come to a consensus on how to define it. While there is no definitively accepted definition of good governance, scholars have conveniently selected any one of those many definitions for their work [1]. This is disturbing news because as we know, the use of different data, variables, and definitions can lead to completely different findings for the same question, as has been noted in civil conflict studies.

Does the concept mean different things to different people and communities? Do states perceive good governance differently?

The idea of good governance may differ between one country and another bringing forth the conception that there is no single, converging, one good governance formula for all countries.

Restraints on leaders, extent of the rule of law, degree of federalism, and regulatory matters all vary, with differences between states, even among liberal democracies [2]. Reference [1] argues that good governance has been a criterion for agencies, intergovernmental organizations, and states providing funds to various countries She notes, however, that there are two differing opinions on whether it should be a criterion for assistance. Our work is however more concerned with Gisselquist's discovery on the "what is" and Andrews" "which" relating to good governance which both studies brilliantly described.

If in fact donor agencies or organizations consider good governance before the provision of funds then this aspect must be incorporated into surveys of perceptions of future Chinese leaders. Part 4 of the survey addresses the good governance area. If good governance is a criterion for agencies, organizations, and investors to decide funding or investment, this question will be able to shed some light on it, at least partially.

Former United Nations Secretary-General Kofi Annan emphasized good governance, especially for Africa which is plagued with governance problems. His idea of good governance stressed on human rights, rule of law, 
transparency, accountability, and effective management of resources [3].

Careful review of the literature linked the concept of good governance to seven elements, namely,

"... democracy and representation, human rights, rule of law, efficient and effective public management, transparency and accountability, developmentalist objectives, and a varying range of specific economic and political policies, programs, and institutions" page 2 [1].

Of the ten definitions highlighted by Gisselquist, nine touched on transparency, seven touched on accountability, six or perhaps seven touched on government capability, efficiency, and ability to transform promises to results/policies, five on participation, four on rule of law, two on corruption, two on independence of institutions, two on eradication of corruption, and one on equity. This clearly shows that good governance is clearly linked to the ideas and principles of democracy, which is not at all a surprising finding.

Even with solid political structures, it is useless if a government cannot transform available political structures to desired policies, such as those that promote development, as Chrzanowski pointed out, addressing the area of government capability and efficiency. Additionally he appended that the concept or definition of good governance is still far from being settled. He however agrees that most definitions hover around accountability, transparency, participation, and rule of law [4].

In trying to incorporate the literature on what constitutes good governance (as described in the preceding two paragraphs), our survey included questions such as the kind of country one would prefer to live in, the importance of democracy, why are rule of law and low corruption good for a country, and acceptance by citizens.

The Measurement of Good Governance

Listed below are some of the commonly used sources of what constitutes good governance:

The Corruption Perceptions Index of Transparency International is a commonly used measure of good governance. Although it measures only one aspect of good governance, level of corruption, it is nevertheless a widely-used measure of good governance. This is an excellent source of good governance index as it is perceptional-based, similar to the survey in our study.

The Freedom House reports highlight accountability, rule of law, freedoms of expression, association, and beliefs, and human rights especially rights of women and minorities. The most widely used measure of Freedom House is the "Freedom of the World" and "Freedom of the Press" reports. Both have four categories; "free," "partly free," "not free," and "worst of the worst." China is in the "not free" category in both reports. Freedom House is a good source of measure for our work because it measures perceptions, at least partly if not completely.

The World Bank World Governance Index (WGI) addresses six dimensions of governance; "Voice and Accountability," "Political Stability and Absence of Violence," "Government Effectiveness," "Regulatory Quality," "Rule of Law," and "Control of Corruption" [5].
The Country Assessment in Accountability and Transparency (CONTACT) of the UNDP creates a way for states to apply its measurement system to test themselves in how closely ranked they are to UNDP's measures of accountability, transparency, integrity, accounting infrastructure, information management, financial reporting, and the control of corruption [6].

The Polity IV project of the Center for Systemic Peace measures a country's authoritarian-democracy score on a scale of -10 to +10 . Measures employed to arrive at a country's polity score are executive recruitment, constraints on executive authority, and political competition. China falls into an average -10 to -6 scale [7]. This source is not one of the more widely-used measures of good governance except for works connected to political science.

Other organizations and agencies have come up with their own measurement scales, for example the APEC, East Asia Barometer, the OECD, and the Minorities at Risk project. Additionally there are centers and organizations dealing with specific regions of the world.

Limitations of the Literature

With so much controversy over conceptual and definitional questions, it is difficult for governments, intergovernmental organizations, and agencies to make decisions whether pertaining to rankings and indexes or pertaining to aid, acceptance into intergovernmental organizations, or forming alliances.

What is interesting is that different good governments employ different methodologies and yet arrive at the same results - efficiency or effectiveness, economic development, reduction of corruption, and the like, as shown by Andrews [2]. It seems the ends seem to converge but not the means.

The majority of definitional and conceptional writings on this topic centers around either international intergovernmental organizations' lists or western lists. This poses a problem since the majority of problems of lack of good governance involve Asian or African states. There is one exception. A number of articles have touched on the Asian Development Bank's (ADB) definition, for example Boas, in 1998, Gisselquist in 2012, and Kaufmann, Kraay, and Mastruzzi in 2009 [8], [1], [9]. The ADB's definition focuses on four major areas; accountability, participation, predictability, and transparency. The Bank's definition of governance hovers around how exactly a state uses available power to cause development, institutions and rules they enact, citizen-citizen interactions, citizen-government interactions, and regulatory frameworks for both the public and the private sector. Therefore, via accountability, efficient and effective management, and achieving goals promised to citizens, good governance is an instrument for the provision of high standards to deal with the areas of governance mentioned above [10].

\section{B. Literature Review on Future Chinese Leaders' Perceptions}

Government is an entity that is run by politicians who make (or amend), enforce, and adjudicate rules or laws. Government also involves allocation of resources. This leads us to question the nature or caliber of that government. This is where the concept of good governance comes into play. For instance, is the enforcement of law in accordance with what 
the legislature intended, or are the courts fair, or are the institutions or structures balanced in power. Another important aspect is what level of quality the government possesses in the task of resource-allocation, whether there is bias and corruption, or is it fair.

There is fairly widespread agreement that the majority of economically advanced states are mature democracies as well, for example, the US, the EU states, Japan, Australia, New Zealand, Canada, and Hong Kong (the long-term independence Hong Kong enjoyed and its current autonomous status allows us to make an exception here even though it is not a state per se). These countries have high scores in the good governance rankings. We therefore see not just a connection between democracy and development but also between democracy and good governance, and between good governance and development. Additionally, low levels of corruption improve a country's good governance ranking. The countries mentioned above all fall into low level corruption within the Corruption Perceptions Index of Transparency International [11]. UAE is the Middle Eastern state that is listed as having the lowest corruption level. UAE is among the most developed and most open Middle Eastern states, clearly highlighting the connection between democracy, development, and good governance. North Korea, Libya, Yemen, Syria, Afghanistan, and many sub-Saharan African countries scored high on the list of corrupted countries in T.I.'s CPI scale. These states are also least democratic and least developed, again highlighting the links mentioned above, except that the reverse is true this time.

Scholars have shed light on the connection between democracy, corruption, and development, for example Chrzanowski found that higher levels of economic development is found more in better governed states. His analysis showed that the lesser the corruption, the better the country is run, and that democracies are better governed than despotic regimes, and communist states plagued with bad governance issues [4]. Even though his work on this specific link focused on the former communist states of Eastern Europe, the findings are particularly important for our work on China here. Reference [2]'s study showed strikingly similar findings to Transparency International's and Chrzanowski's. He found that OECD and EU states were high up in the ranking index of "Government Effectiveness Score" while all other states scored lower than them, indicating that states practicing good governance (that is, democracies or better economically developed states) end up being more effective or efficient. The paper's survey questions address the literature's question of corruption. It asks respondents to rank countries based on the level of corruption. This gives us an idea of where China lies in that scale.

The majority of democracies also practice capitalism. Capitalism is closely knitted to democracy. Therefore a point to note is that the democracy-good governance-development (or democracy-development-good governance) nexus may be replaced with a capitalism-good governance-development (or capitalism-development-good governance) nexus.

While the link between the various aspects shown above (democracy/capitalism, good governance, and economic development) is fairly clear, we needed to include China in the equation. It is no surprise to classify China as neither a democracy nor a market economy. Further, China's corruption level is high. However, China's development is high as well. China is therefore an exception to the democracy/capitalism-good governance-development link. China's economic progress was at the expense of commonly (or widely) accepted notions of what a good government should be. We revisit what has been mentioned-good governance is what countries make of it, as postulated by Andrews [2]. As China has clearly accentuated this fact, we may be walking the wrong path if we adopt a one-recipe-fits-all formula mentality. The survey questionnaire tests this anomaly, revealing the key to understanding if future Chinese leaders are more concerned about good governance or if they are concerned about the overall well-being, and if they are willing to sacrifice good governance for economic well-being and peace. The questions also elicit the reverse-if one prefers to live in a democratic country even without the guarantee of economic security or domestic tranquility. Additionally questions test if future leaders really care about the democracy angle of good governance. Questions also draw respondents' perceptions about regime stability, to check if future leaders perceive good governance from the widely-accepted western point of view or they have a unique construct of it.

These questions also test Andrews' logic that different countries perceive the meaning of what constitutes good governance differently. They also confirm or refute Chrzanowski's postulation that even with solid political structures, it is useless if that government cannot transform available political structures to desired policies, such as those that promote development. Chrzanowski's capability and efficiency criteria fit well with more than six of widely-accepted good governance criteria.

The survey for this study may seem a little too subjective. It is important to point out at this juncture that many highly respectable surveys are highly subjective and perceptions-based. Reference [9] brings to our attention the World Bank Indicators (WGI) surveys, arguing that this data is purely subjective and perceptions-based, yet highly reliable because

“... perceptions matter because agents base their actions on their perceptions, impression, and views. If citizens believe that the courts are inefficient or the police are corrupt, they are unlikely to avail themselves of their services ... few alternatives to relying on perceptions data ... particularly so for the case of corruption ..." page 4 [9].

We cannot measure every single variable objectively especially in works forecasting the future. Questions pertaining to facts such as respondents' views about FDI or democracy levels may be measured via objective facts. However views on China's corruption level, efficiency, success/failure, the ideal state, quality of government, and trust in and satisfaction with the government simply cannot be measured objectively.

\section{Methodology}

Designing questions that will truly gauge attitudes is vital to the success of this research. In order to find out attitudes as 
accurate as possible, the paper designed questions to this end. In other words, we need to know first if respondents are largely satisfied with the current issues of the country, then we want to find out if they are optimistic or pessimistic with the situation in the next five to ten years.

\section{A. Questions Pertaining to Governance/Good Governance}

The paper's first question about politics is straightforward. We want to know what the students want their government to do for them. We ask "what is the most important function of a government?" and provided them the following choices:

1) Raise the standard of living for its people

2) raise the international status of its country in the world

3) build a large and powerful army for its country

4) bring democracy and rule of law

5) ensure freedom of religion.

The first three choices are the ones that the Chinese regime has often emphasized in justifying its policies and its propaganda. The last two are the ones the Western government and media have been propagating most strongly and routinely, which are also what the western governments have carried out in actual policies around the world. The priority of these issues among the students will inform us if they are more supportive of the Western or the Chinese government's side of story.

The second question also involves attitude analysis, which asked them to rank order the importance of the following issues:

1) people can vote their government official

2) political stability and no violence in society

3) government effectiveness in implementing policies

4) rule of law in the society, and

5) control of corruption.

These indicators are derived from the World Bank Indicators with minor adaptations. The choices cover almost all political aspects of a government. The responses of the students will allow us to understand the relative urgency and whether the Chinese regime does conform to what their needs and interests are. Additionally this is compared to the U.S. side.

Question 3 asks them candidly about their opinion on democratic transformation, which is a very sensitive topic in China for obvious reasons. We are interested in knowing their eagerness and determination for pushing forward democratization in China, and in the U.S., if maintaining democracy is a priority. Five possible choices were provided for them after having made them aware of the possible risks in democratization. The level of acceptance of risks will inform us of their level of satisfaction with the status quo. If they are eager for a change and are willing to take all the related risks, it implies that they are dissatisfied with the current system; otherwise they would be more conservative about possible political changes. The choices for them are as below:

1) I will take whatever consequences so long as democracy can be achieved.

2) I will support if transition to democracy comes with economic growth.

3) I will support if transition to democracy does not take more than 3 - 5 years.
4) I will support if transition to democracy does not take more than 10 years.

5) I will not support it if the result is unpredictable and price high.

Question 4 asks them about the issue of corruption since it is a well-known fact that corruption is a very serious issue in China. Listed are a total of five countries in the world. Respondents are asked to rank order these countries according to their level of corruption. Countries selected are major countries that have relatively high exposure on China's media and the students have sufficient knowledge of them. Selected are Canada, India, Japan, and Russia. Canada is a long term democracy and a country that frequently appears in China's media; Japan is both a democracy and a neighbor, and a country that has a complicated history with China; India is a close neighbor of China, which is a democracy but it is also a developing country as well as an economic competitor; and Russia is a former communist country, China's once ideological mentor and a newly democratizing state. Canada and Japan are both politically cleaner than China. Transparency International classifies Russia and India as more corrupt than China even though India is democratic. The unique situation of each case allows ideal comparisons.

Question 5 targets the relative level of "approval rating" of these countries. We want to find out how the students view their own government in comparison with four representative governments, eliciting students' approval rating of the status of the Chinese regime and the U.S. government.

The sixth and the last question serve as a summary or confirmation of their attitudes, providing a choice between:

1) A society that has higher standard of living (higher income) but the government is authoritarian;

2) A society that has lower standard of living (lower income) but the government is clean and proper.

Question 6 intends to gauge their attitude towards the relative weight of standard of living versus good government. This question will also test eagerness for democratization.

Respondents' answers to these six questions will provide us with vital information on the views of future Chinese and American leaders. If the survey finds that China is moving away from autocracy to democracy and openness, and is practicing, or beginning to practice good governance, then we may assume that Southeast Asia is becoming a safer region.

\section{B. Methods and Issues about Data Collecting}

To make the sample as representative as possible, the research included universities of all tiers and all regions. These included China's Project 211 elite universities in the central regions, such as Peking University, China Foreign Affairs University, and Shanghai Jiaotong University, as well as the less elite, local universities. Other universities surveyed fall in between, in terms of academic ranking and region.

Student composition is pretty comprehensive, covering students in Natural Science and Engineering as well as in Humanities, Social Science, and Business. Both undergraduate and graduate students were surveyed; about twenty percent graduate students. To ensure that only the sample is surveyed, a password is needed to take the survey. To satisfy the requirements of typical Human Subject 
Research, students below 18 were required to obtain parent(s) permission. By the end of 2015, 25 Chinese universities and almost 15 American universities were surveyed totaling more than 1000 valid responses. Approximately fifty-five percent of the respondents are female students and forty-five were male students.

\section{RESUlTS AND DISCUSSION}

\section{A. The China Survey Results}

The responses to the first question are presented in Fig. 1. A predominant $61 \%$ of the respondents chose "raise the standard of living for its people," which is more related to material wealth. The least selected one is "ensure freedom of religion". These results show that the students are more concerned with the material things in politics, rather than other things which are more abstract, such as "international status", "building a powerful army", "democracy" and "religion." The Chinese regime's policy of priority on "economic construction" is well echoed by the students. Even so, there is one thing that we cannot neglect-at least a quarter of the respondents preferred "democracy and rule of law" to "raise the standard of living" as the most important function of a government. This finding has profound implication. Although a majority of the students emphasize economic development and financial benefits, there are still a substantial number of students who prioritized social justice and political representation. It is no doubt that economic concerns overshadow political and social discontents nowadays. However the longing desire to seek liberty and freedom has never been truly gone.

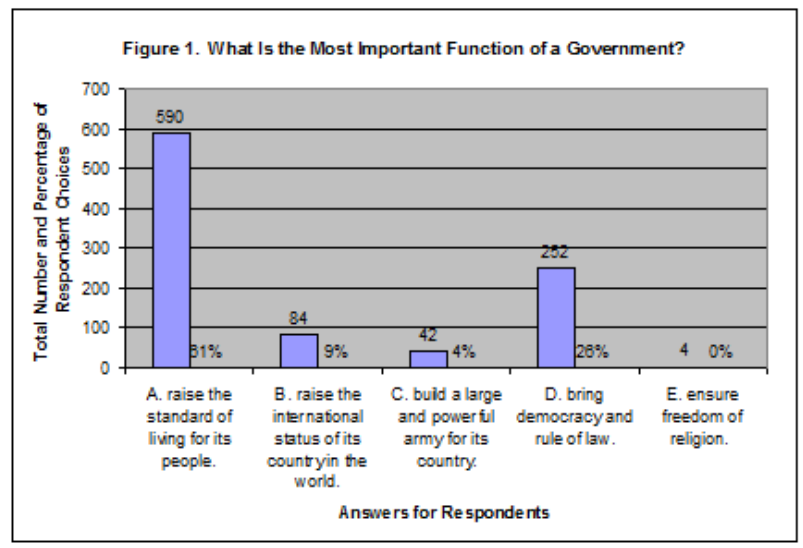

Fig. 1. The most important function of a government.

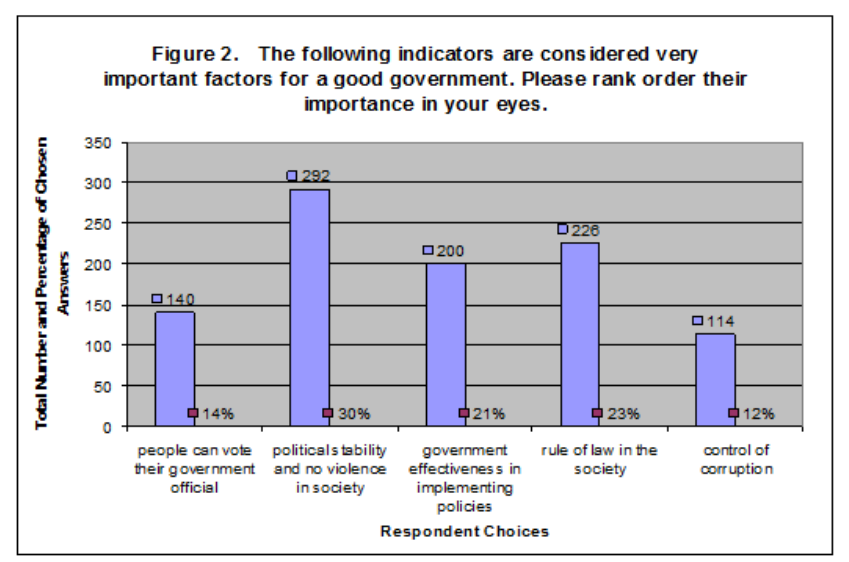

Fig. 2. Indicators very important for a good government.

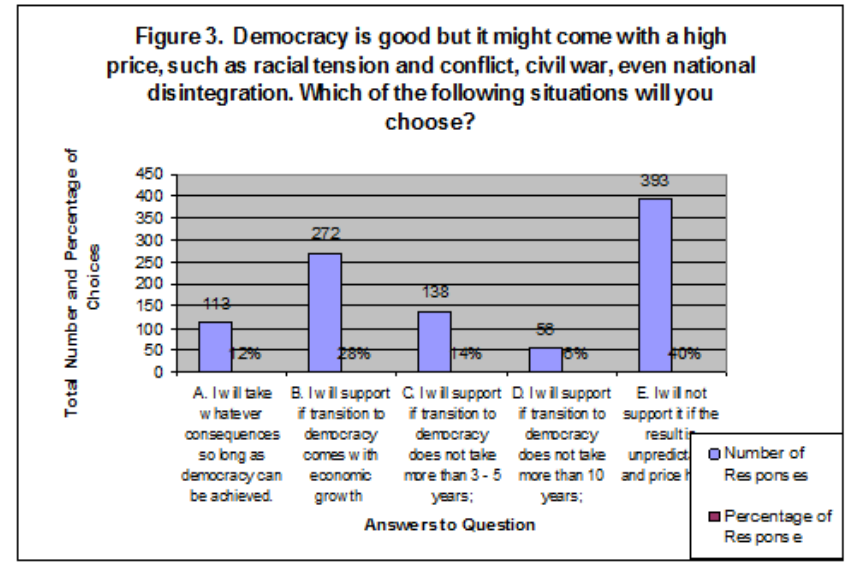

Fig. 3. Choosing a particular situation associated with democracy.

Fig. 2 presents the results about the most important factors for a good government. Among all the factors, the highest selected factor is "political stability" $(30 \%)$ while the least selected is "control of corruption." (12\%) The indicator that is most closely related to democratic election "people can vote their government official" ranks the second lowest $(12 \%)$, which may suggest that "political stability" of China is the more concerned issue for them rather than the introduction of democratic rule. They also value "rule of law" $(23 \%)$ and "government effectiveness in implementing policies" $(21 \%)$. The latter seems more distant from democratic election.

Fig. 3 presents the results of the outright and candid question about democratic transformation. The results seem to confirm their attitude in question 2, that is, their interest in democratization is not strong, as forecasted by many advocates of democracy. A dominant $40 \%$ of the respondents chose "I will not support it if the result is unpredictable and price high." The second highest chosen is $28 \%$, which is "I will support if transition to democracy comes with economic growth." Ironically only $12 \%$ chose "I will take whatever consequences so long as democracy can be achieved." This is the second least selected answer. Such results show that the college students in China view democratic transition with more rationality. They do not view democratic transition simply for the sake of democratic transition. They believe only by bringing the society with actual benefit, such as economic growth, would they choose democratization.

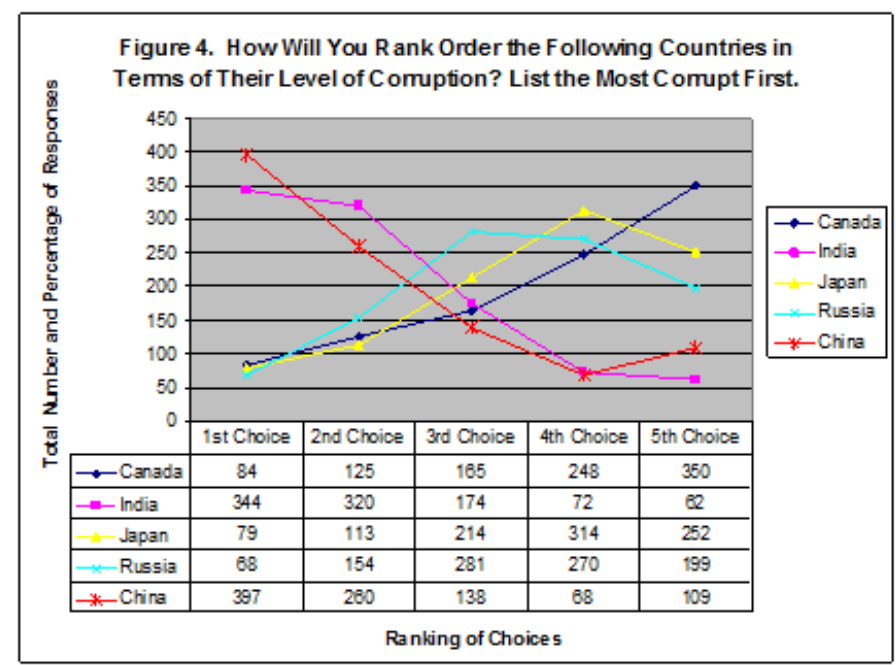

Fig. 4. Ranking countries by corruption levels. 
Fig. 4 shows the perception of the level of corruption. The figure shows clearly that China and India's pattern are very similar to each other-both countries are ranked by a predominant number of respondents as the first choice of the most corrupted countries. China is regarded as an even more corrupt country than India. The other three countries are also similar - a significantly lower percentage of respondents list them as the most corrupt countries. In their second choice, both China and India are still listed by a significantly higher number of students as the most corrupt countries among the five countries. Canada performs the best, consistently being listed as the least corrupted country. Japan is the second cleanest country, and Russia ranks the third.

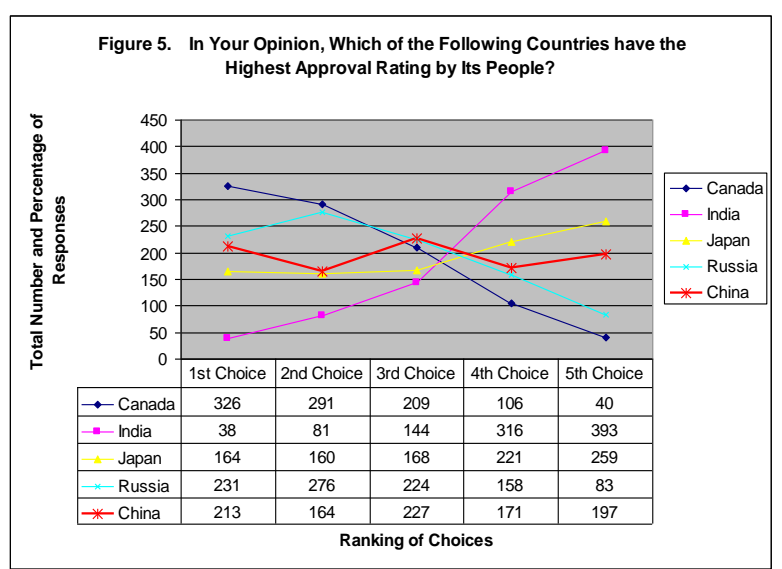

Fig. 5. Ranking countries by citizens' approval rating.

Figure 6. In which ONE of the following societies will you choose to live?

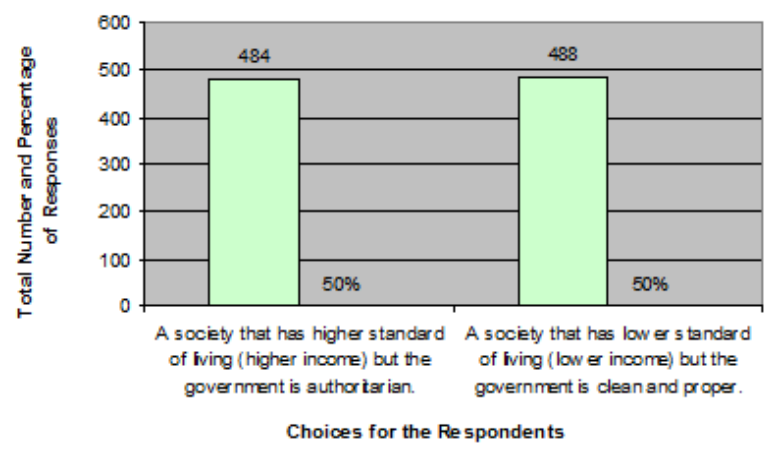

Fig. 6. Selection of the better society to live in.

Despite the fact that China was regarded as the most corrupt country among the five, the approval rating of China is not that bad as shown in Fig. 5. Canada is constantly believed to have high approval rating. Overall Russia ranks the second. China is in the middle of the five. Japan ranked the fourth and India is consistently believed to be the country that has the lowest approval rating.

Question 6 surveyed the kind of society they preferred to live in. Fig. 6 demonstrates a tie between the group who are willing to trade political freedom for higher standard of living and the group that wishes the opposite. If we understand this tie as that half of the students are willing to sacrifice higher standard of living for political freedom and clean government then the other are not willing to accept this trade-off. Instead they are more willing to accept less political freedom for higher standard of living. Under this circumstance, half of the respondents will become the inhibiting force for another risky democratic movement. This may suggest that China's current authoritarian system will last a long while so long as the regime is capable of providing higher standard of living to the society continuously and handling successfully other possible issues sensitive to the students.

\section{B. The U.S. Survey Results as Compared with the China Results}

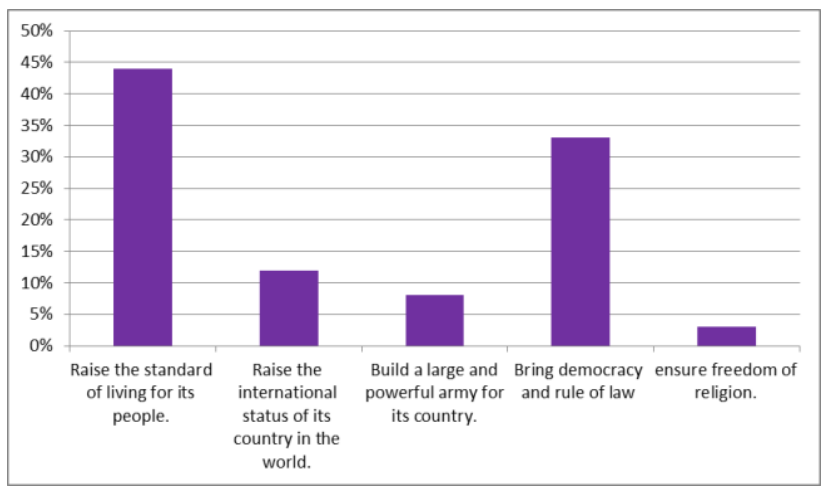

Fig. 7. The most important function of a government.

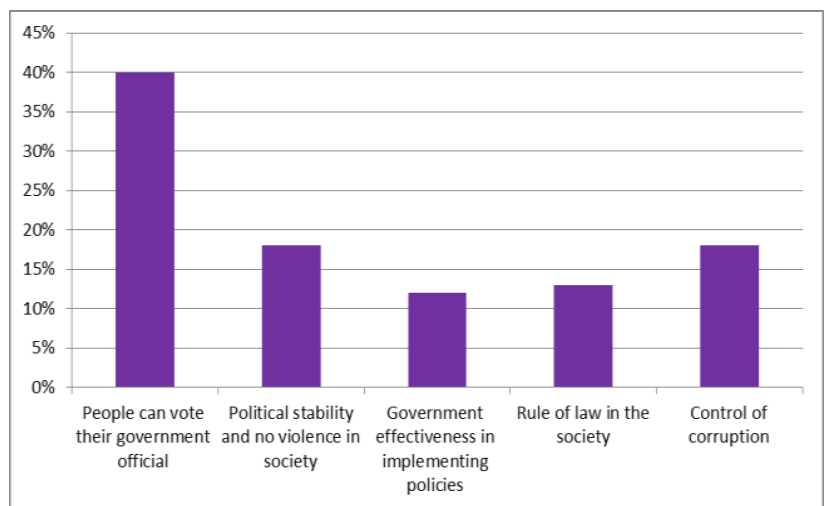

Fig. 8. Indicators very important for a good government.

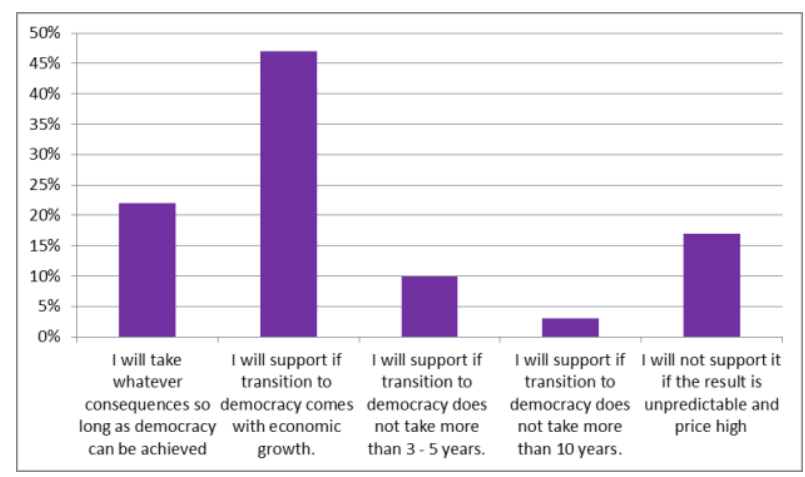

Fig. 9. Choosing a particular situation associated with democracy.

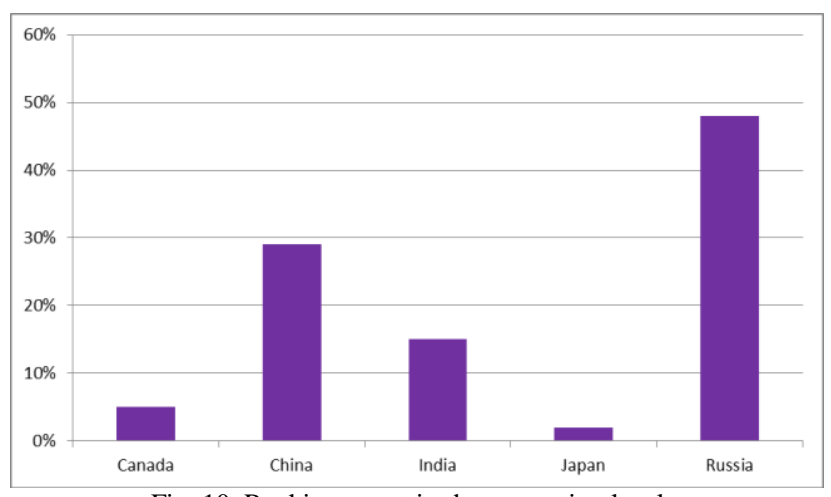

Fig. 10. Ranking countries by corruption levels. 


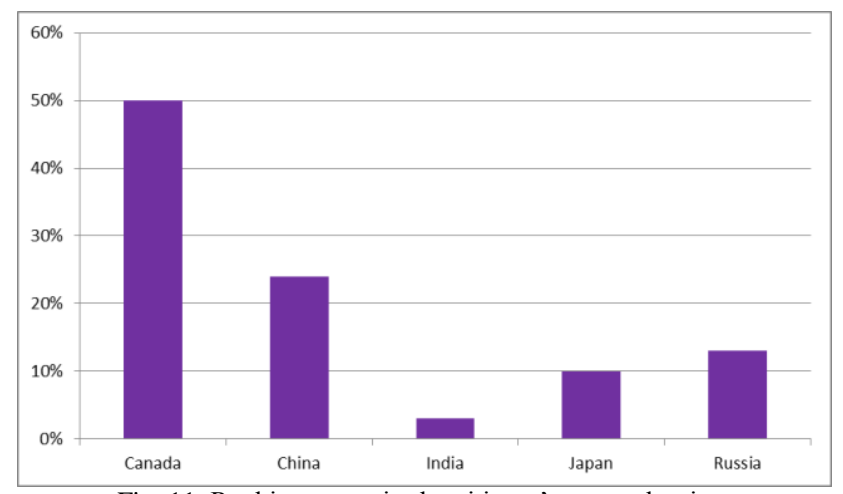

Fig. 11. Ranking countries by citizens' approval rating.

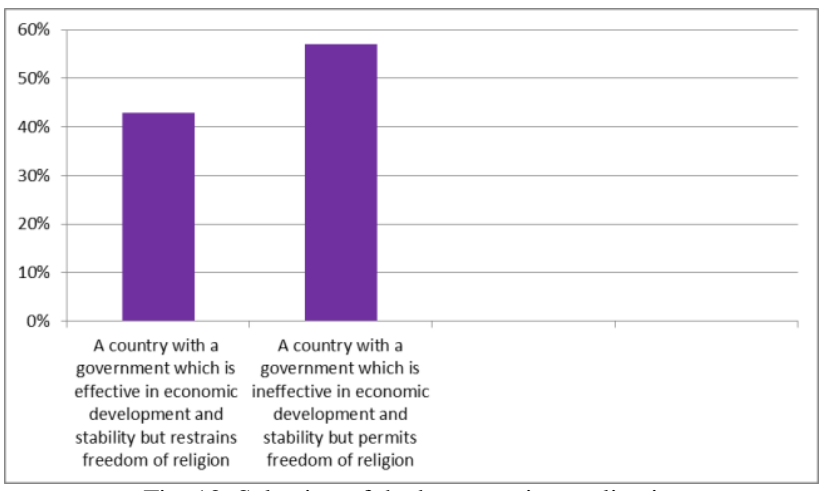

Fig. 12. Selection of the better society to live in.

The result in Fig. 1 above is exactly as seen in the China survey. The predominant responses are raising the standard of living followed by bringing democracy and rule of law, indicating that future US leaders are more concerned with material wealth. The least selected one is "ensure freedom of religion". These results show that the students are more concerned with the material things in politics, rather than other things which are more abstract, such as "international status", "building a powerful army", "democracy" and "religion." Although a majority of the students emphasize economic development and financial benefits, there are still a substantial number of students who prioritized social justice and political representation. While it is no doubt that economic concerns overshadow political and social discontents but the desire to maintain existing liberties and freedoms are still solid.

The result in Fig. 2 presents the results about the most important factors for a good government. Among all the factors, the highest selected factor is the indicator that is most closely related to democratic election "people can vote their government official" (40\%) while the least selected is government effectiveness (less than 10\%). Both political stability and control of corruption were second most popular choices (about 18\%). The results, unlike the first question, were different from the China results. Americans are more concerned about political freedoms than Chinese who are more concerned about national stability. Americans are less concerned about efficient government and more about clean government rather the Chinese are least concerned about democratic elections and clean government.

Fig. 3 presents the results of the outright and candid question about democratic transformation. The results indicate the wish to maintain democratic traditions. Even though they will support democracy with the condition that it should be accompanied by economic growth, the second highest choice of causing or maintaining democracy at any cost clearly shows the desire to maintain this ideology. The Chinese however will not support democracy if the future is unpredictable. Rather, any move towards democracy must be accompanied by economic progress, even if they have to wait for more than 10 years. Americans on the other hand are willing to take risks which accompany democracy.

Fig. 4 above shows the perception of the level of corruption. Both U.S. and Chinese students agree that Japan and Canada are the cleanest states and that China and India are corrupt. The only difference is that US students consider Russia as the most corrupt while Chinese students consider India as the most.

Fig. 5 indicates that Canada is considered to have the greatest approval by its citizens. Chinese students think that both China and Russia have high approval ratings of their citizens. We may assume that this is due to the fact that the survey was done by Chinese students. Interestingly, this is not the case as even the US respondents share that view. Future Chinese leaders approve of their government in spite of human rights violations and authoritarian laws. It would be interesting to witness how the respondents will respond if China's economy is on par with slow or average-growth economies.

Question 6 (see Fig. 6) surveyed the kind of society they preferred to live in. For the US there is a clear difference; more than $55 \%$ would forgo economic progress for democratic/religious freedoms, which is typical for the US. For China there is a tie between the group who are willing to trade political freedom for higher standard of living and the group that wishes the opposite. From the responses from previous questions, we would have expected that more respondents would pick forgoing democracy and freedoms for economic progress but that is not the case. We probably need to revisit this question and conduct a repeat survey for this particular question to ascertain the validity. One way is to offer more than two choices.

\section{CONCLUSION}

Based on the responses to our six questions about China's politics, we can observe that the current college students' interest (future generation interest) in economic benefits today is much stronger and salient compared to their passion for changing the politics of China. The current regime seems to have addressed their major concern in providing political stability (Fig. 2) and economic development (Fig. 1) even though they think China is the most corrupt country among the five listed ones (Fig. 4). In terms of democratic transformation, their eagerness for embracing it is much less noticeable compared to their interest in other issues (Fig. 1). And they actually are even very conservative about political change and are likely to support it only if the change is coupled with economic growth. Very few of them will support democratic transformation simply for the sake of democracy (Fig. 3).

If the survey study can catch the real views and attitude of currents college students in China toward their government, the responses from them do not provide any solid evidence implying that they want a regime change. What the current government has done seems to conform to what the students 
want to see and possess - economic well-being rather than any unpredictability of political changes. This means that they do not have any obvious discontent, hence the motivation or activism in pushing their government to make any major political or economic changes, though it does show their serious worries about the corruption in the country. The students are more concerned with economic benefits and the quality of life than political rights (as some literature and politicians in the West strongly advocate). Even though they believe China is the most corrupt country in the group of five, future generation's approval of China is not low at all. The US results indicate the desire for democracy or the maintaining of existing democratic values and traditions. It is interesting to note that political concerns and freedoms outweigh economic desires. There is some evidence of the desire to accompany economic progress with democracy but this could be due to the current economic setback in the US. The results indicate that America's future generation is not willing to sacrifice democracy and political freedoms simply to achieve economic affluence. This is exactly the opposite of China's future generation, which clearly shows disconnect between the wishes of the U.S. and China. This is perilous to the region as shown by the disagreements in the South China Sea issue. While the current political environment does not seem too promising, the survey shows that future leaders of both countries wish for a status quo for their respective states making the future not very encouraging.

The post-Tiananmen crackdown generation seems very different from their predecessors. Their interest in economic well-being is significantly greater than their interest in politics and the current regime does satisfy their needs in this area. The benefits of China's great economic success have reached them. On the contrary, the democratization movement that has spanned across the former communist regions and today's Arab world has not provided a positive lesson for this generation thus forcing Southeast Asia to ponder over engaging and bandwagoning versus balancing and containing China. The CCP has successfully met the students' need in material concerns by creating the economic miracle, and, at the same time, satisfied their patriotic or nationalistic need by raising the status of China and strengthening their national pride.

\section{REFERENCES}

[1] G. Rachel,. "Good governance as a concept, and Why this matters for development policy," WIDER Working Paper Number 2012.

[2] A. Matt. "Good governance means different things in different countries," Governance: An International Journal of Policy, Governance, Administration, and Institutions, vol. 23, no. 1, pp. 7-35.

[3] United Nations. (1998). The causes of conflict and the promotion of durable peace and sustainable development in Africa. Report of the UN Secretary-General, April 1998. [Online]. Available: https://www.issafrica.org/uploads/CAUSECONFLICT

[4] C. Ignacy. (2014). "Good governance as prerequisite for a sound economy," Kwartalnik Nauko Przedsiębiorstwie, vol. 1, pp. 14-26.

[5] World Bank. (2015). [Online]. Available: http://info.worldbank.org/governance/wgi/index.aspx\#home, Retrieved October 28, 2015
[6] B. Marie, Good Governance Rankings: The Art of Measurement, World Peace Foundation Reports Number, vol. 36, 2003.

[7] Polity IV Project. (2014). Center for Systemic Peace, Virginia, USA [Online]. Available: http://systemicpeace.org/polity/polity4.htm

[8] B. Morten, "Governance as multilateral development bank policy: The cases of the African development bank and the Asian development bank," The European Journal of Development Research, vol. 10, pp. 117-134, 1998.

[9] K. Daniel, A. Kraay, and M. Mastruzzi. Governance Matters VIII: Aggregate and Individual Governance Indicators1996-2008, The World Bank Development Research Group Macroeconomics and Growth Team Policy Research and Working Paper 4978, 2009.

[10] Asian Development Bank, Governance: Sound Development Management, Report, 1995.

[11] Transparency International. (2014). [Online]. Available: http://www.transparency.org/cpi2014/results Retrieved November 1, 2015

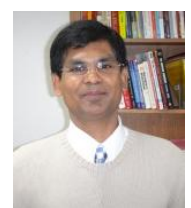

Sugumaran Narayanan is a political science professor at Midwestern State University, Texas, USA. He has been with this institution for about 8 years now. He obtained his $\mathrm{Ph} . \mathrm{D}$. from the University of Alabama in 2008 with a major in International Politics and a minor in American Politics. While his areas of expertise are international politics and civil conflicts, he has a keen interest in US presidential politics. Dr Narayanan has carried out both quantitative and qualitative scholarly work. Recently he carried out field work pertaining to civil wars in Southeast Asia as well as visits to peaceful Native communities. In doing so he compares the correlates of war with peace. In his civil war field work research he held discussions with interesting personalities; rebel leaders, heads of governments (for example former Prime Minister Dr Mahathir Mohamad and former President Noynoy Aquino), former First Lady Imeda Marcos, mediators of peace talks etc. Prior to joining higher education he has worked in public multinational organizations.

Dr. Narayanan has been bestowed with various awards and recognitions. $\mathrm{He}$ has presented in numerous conferences, acted as Chair/facilitator of sessions, and delivered keynote addresses and invited talks.

During President Obama's first term, he participated in invited roundtable discussion along with about 50 persons worldwide to discuss human rights conditions in various countries in U.S. State Department's "Roundtable over Human Rights", chaired by State Department Assistant Secretary Michael Posner. Additionally, also during the Obama first term, he was invited to judge/rate important federal government contests, nominate community exemplary figures for Presidential medals of honor, and participated in invited White House conference calls and policy meetings.

Dr. Narayanan is also a board member, Malaysian-American Foundation.

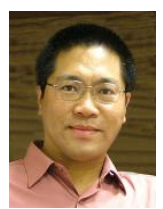

Wanfa Zhang is an associate professor of political science in the School of Arts and Communication at Florida Institute of Technology, USA. He was previously a lecturer at China Foreign Affairs University and the author of several articles published in China Journal of American History and Journal of Foreign Affairs College. He was also a contributor of entries in the Dictionary on China's Diplomacy and the author of book chapters, journal articles and book reviews published in the US and other countries.

He has been invited as a guest speaker to give talks on international and Chinese politics at other colleges, on TV or in the public library in both the US and China. He has also served as chair or member of best paper award committees of international academic organizations or reviewer for highly esteemed journals of his discipline. He currently serves as a board member of the Association of Chinese Political Studies, USA. His research interests include great power politics, quantitative study of international conflict, contemporary Chinese politics and diplomacy, and security issues in the Asia-Pacific region. He once worked as a research assistant collecting data for the very influential Correlates of War (COW) project. His most recent research is an ambitious 10 -year long project that aims to create a big time-series dataset for researching long-term public attitude shift towards power distribution change in the international system. This article is a partial result of that project. Zhang received his Ph.D. from the University of Alabama, Tuscaloosa, USA, in 2009 